УДК 581.92:582.579.2(598+597)

\title{
The iris family (Iridaceae) in the flora of eastern Indochina
}

\author{
L. V. Averyanov ${ }^{1}$, E. V. Boltenkov ${ }^{1}$ T. V. Maisak ${ }^{1}$, Khang Sinh Nguyen ${ }^{2}$, Hiep Tien Nguyen ${ }^{3}$ \\ ${ }^{1}$ Russian Academy of Sciences, Komarov Botanical Institute, Prof. Popov, 2; St. Petersburg, RF-197376, Russia \\ ${ }^{2}$ Institute of Ecology and Biological Resources, Vietnam Academy of Science and Technology, \\ 18 Hoang Quoc Viet, Cau Giay, Ha Noi, Vietnam \\ ${ }^{3}$ Center for Plant Conservation, No 25/32, lane 191, Lac Long Quan, Nghia Do, Cau Giay, Ha Noi, Vietnam
}

Key words: Iridaceae, Iris, eastern Indochina, Laos, Vietnam, plant diversity, taxonomy.

Summary. Iris family in the countries of eastern part of Indochina Peninsula, such as Cambodia, Laos and Vietnam includes lone native genus - Iris L. with two aboriginal species - I. japonica Thunb. and I. tectorum Maxim. Iris japonica is often cultivated as an outdoor ornamental plant in mountainous regions in the northern Vietnam, where it occasionally naturalizes. Herbarium specimens of I. japonica, collected in central Laos near Nape town, probably represent southernmost locality of the Iris genus in Eurasia. Iris tectorum was discovered in native, primary plant communities of karstic highly eroded limestone in Cao Bang province (Bao Lac district) of the northern Vietnam. This species is recorded as new for the flora of the Indochina Peninsula. The report of I. collettii Hook. f. on the territory of peninsular flora does not yet confirmed by herbaria and remains doubtful. Data on taxonomy, authentic specimens, distribution, habitats, phenology, conservation status and biology are provided for all Iris species. The identification key for Iris species is compiled, as well as dotted distribution maps on the territory of countries of eastern Indochina. Other representatives of the family from such genera as Belamcanda Adans. (B. chinensis (L.) Redouté), Crocosmia Planch. $(C . \times$ crocosmiiflora (G. Nicholson) N. E. Br.), Eleutherine Herb. (E. bulbosa (Mill.) Urb.), Freesia Klatt (F. refracta (Jacq.) Klatt.), Gladiolus L. (numerous horticultural forms) и Trimezia Salisb. ex Herb. (T. martinicensis (Jacq.) Herb.) reported from Indochina are introduced cultivated ornamental plants capable to occasional naturalization as an adventive element of the Indochinese flora.

\section{Семейство касатиковых (Iridaceae) во флоре восточного Индокитая}

\author{
Л. В. Аверьянов ${ }^{1}$, Е. В. Болтенков ${ }^{1}$, Т. В. Майсак ${ }^{1}$, Кхан Синь Нгуен $^{2}$, Хьеп Тьен Нгуен \\ ${ }^{1}$ Ботанический институт им. В.Л. Комарова РАН, ул. Проф. Попова, 2; Санкт-Петербург, 197376, Россия. \\ E-mail:av_leonid@mail.ru; av_leonid@yahoo.com \\ ${ }^{2}$ Институт экологии и биологических ресурсов, Академии наук и технологии Вьетнама, 18 Хоанг Куок Виет, \\ Кай Гиау, Ханой, Вьетнам. E-mail: khangnguyensinh@yahoo.com

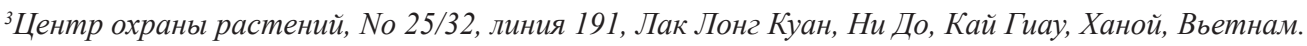 \\ E-mail: hiep.nguyen@cpcvn.org
}

Ключевые слова: Iridaceae, Iris, восточный Индокитай, Лаос, Вьетнам, разнообразие растений, таксономия.

Аннотация. Семейство Iridaceae в странах востока полуострова Индокитай (в Камбодже, Лаосе и Вьетнаме) включает один аборигенный род - Iris L. с двумя видами - I. japonica Thunb. и I. tectorum Maxim. Iris japonica нередко выращивают как декоративное растение открытого грунта в горных районах на севере Вьетнама, где этот вид, по-видимому, может легко натурализоваться. Гербарные образцы I. japonica, собранные в центральном Лаосе в окрестностях города Напе, вероятно, представляют самое южное местонахождение вида рода Iris в Евразии. Iris tectorum был найден в естественных растительных сообществах скальных карстовых известняков провинции Каобанг (район Бао Лак) на севере Вьетнама. Этот вид приводится для флоры полуострова Индокитай впервые. Указание I. collettii Hook. f. на территории флоры не подтверждено гербарными 
сборами и остается сомнительным. Для всех видов приведены данные о таксономии, аутентичном материале, распространении, характере мест обитания, фенологии, охранном статусе и биологии. Предложен ключ для определения видов рода Iris, их иллюстрации и карты распространения в странах восточного Индокитая. Остальные представители семейства, указываемые для территории флоры из родов Belamcanda Adans. (B. chinensis (L.) Redouté), Crocosmia Planch. (C. × crocosmiiflora (G. Nicholson) N. E. Br.), Eleutherine Herb. (E. bulbosa (Mill.) Urb.), Freesia Klatt (F. refracta (Jacq.) Klatt.), Gladiolus L. (numerous horticultural forms) и Trimezia Salisb. ex Herb. (T. martinicensis (Jacq.) Herb.) являются культивируемыми иноземными растениями способными к случайной натурализации в качестве адвентивного элемента флоры.

The fairly large iris family (Iridaceae Juss.) is well known for many ornamental genera like Crocosmia Planch., Crocus L., Dietes Salisb. ex Klatt, Freesia Klatt, Gladiolus L., Iris L., Sisyrinchium L., Tigridia Juss., Trimezia Salisb. ex Herb., Tritonia Ker Gawl., and others. The family contains 70-80 genera with about 1700 species having almost worldwide distribution with highest diversity in southern Africa and temperate mainland Asia. Meanwhile, the iris family is scarcely presented in the flora of eastern Indochina including Cambodia, Laos and Vietnam. Only three native species of Iris are presently reported here additionally to some introduced and occasionally naturalized ornamental exotics from such genera as Belamcanda Adans. (B. chinensis (L.) Redouté), Crocosmia $(C . \times$ crocosmiiflora (G. Nicholson) N. E. Br.), Eleutherine Herb. (E. bulbosa (Mill.) Urb.), Freesia (F. refracta (Jacq.) Klatt.), Gladiolus (numerous horticultural forms), Trimezia (T. martinicensis (Jacq.) Herb.), recorded for urbanized areas of the region (Gagnepain, 1934; Ho, 2000; Nguyen, 2005).

Taxonomic treatment of native iris species is presented below. One species is reported for the area at first. Brief data on taxonomy, types, distribution, habitat, phenology, conservation status, notes on biology are presented for each species, as well as key for their identification, illustration and map of distribution in eastern Indochina.

\section{Taxonomic treatment}

Iris L. 1753, Sp. P1. 1: 38; Gagnep. 1934, Fl. Indo-Chine, 6, 5: 673-675; P. H. Ho, 2000, Ill. Fl. Vietnam, 3: 504; Y. T. Zhao \& al., 2000, Fl. China, 24: 297-313; T. D. Nguyen, 2005, Checkl. Pl. Sp. Vietnam, 3: 481.

Type $-I$. germanica L.

200-300 species in temperate and subtropical zone of Northern Hemisphere. In Vietnam 3 species (one species is reported here at first).

\section{Key to species}

1. Roots clustering, more or less swollen or fusiform; plants densely tufted with many dense short erect shoots, leaves clustering into dense fascicle, less than $1 \mathrm{~cm}$ wide ............................. 1. I. collettii

- Roots distant, thin, not tuberous; plants with creeping rhizomes or with erect stems, leaves clustered into flat terminal fan, more than $1 \mathrm{~cm}$ wide ...

2. Plants with semi-woody, short rigid ascending rhizome, stem erect, semi-woody, to $1(1.5) \mathrm{m}$ tall; inflorescence branched, normally $20-50 \mathrm{~cm}$ long, with many pale blue to almost white flowers 4-5.5(6.5) cm across; sepals and petals hardly unguiculate; sepals denticulate along margin, apices of stile lobes long fimbriate; sepal srest lamellate to almost flat 2. I. japonica

- Plants with thick creeping plagiotropic rhizome, stem fleshy herbaceous, ascending, 1-2(3) $\mathrm{cm}$ tall; inflorescence simple, 10-15(20) cm long, with 1-2(3) dark blue flowers (8)10-13 cm across; sepals and petals distinctly unguiculate; sepals entire along margin, apices of stile lobes bilobulate, entire or slightly denticulate; sepal crest long fimbriate

3. I. tectorum

1. Iris collettii Hook. f. 1903, Bot. Mag. 129, tab. 7889; Y. T. Zhao et al., 2000, Fl. China, 24: 306.

$\equiv I$. nepalensis D. Don f. depauperata Collett et Hemsl. 1890, J. Linn. Soc., Bot. 28: 136.

$=I$. nepalensis var. letha Foster, 1892, Gard. Chron. ser. 3, 12: 458.

=I. duclouxii H. Lév., 1908, Repert. Spec. Nov. Regni Veg. 6: 113.

Described from northern Myanmar ("Shan Hills").

Syntypes ("Shan Hills, Pwehla, 4000 feet, May 1888, H. Collett 765") - CAL, K [K000098494].

Habitat, phenology and conservation status. Terrestrial tufted herb. Open Pinus and QuercusPinus forests, sunny dry grasslands. (600)1700$3700 \mathrm{~m}$ a.s.l. Flowers in May - June. Not common. Estimated IUCN Red List status - DD.

Distribution. Vietnam?, NE India, SW China, Myanmar, NW Thailand.

Notes. This mountainous species closely related to widespread I. decora Wall. (= I. nepalensis $\mathrm{D}$. Don, nom. illeg.) was recorded for Vietnam in 
second edition of Flora of China (Zhao et al., 2000) without confirmation by voucher herbaria. We can not trace any specimens of this species originated form Vietnamese territory. Hence, occurrence of this rather highland plant in Vietnam needs confirmation. Data on ecology and phenology are reported here based on specimens collected outside Vietnam.

2. Iris japonica Thunb. 1794, Trans. Linn. Soc. London, 2: 327; Gagnep. 1934, Fl. Indo-Chine, 6, 5: 675, fig. 67, 1; P. H. Ho, 2000, Ill. Fl. Vietnam, 3: 504, fig. 9712; Y. T. Zhao et al., 2000, Fl. China, 24: 307; T. D. Nguyen, 2005, Checkl. Pl. Sp. Vietnam, 3: 481 .

$\equiv$ I. squalens Thunb. 1784, Fl. Jap. 2: 33, non L. 1759, nom. illeg.

=I. chinensis Curtis, 1797, Bot. Mag. 11: tab. 373.

=I. fimbriata Vent. 1800, Descr. P1. Nouv. 1: 9, tab. 9.

Fig. 1, 2.

Described from Japan ("Japonice: Saga, it. Siaga").

Type ("E Japonia, s. d., [Thunberg] s. n.") - UPS [UPS-THUNB 1138].

Studied specimens. N. Vietnam, Tonkin, Cha pa, 11 Janvier 1912, M. Mieville 9(P). Central Laos, env. De Nape, 13 Octobre 1928, M. Delacour (P). N. Vietnam, Tonkin, Chapa, 1500 m., Janvier 1928, Petelot 5099 (P). N. Vietnam, Tonkin, San-tanngai, Lai Chau, 1650 m., 3 Octobre 1936, Poilane 25630 (P). N. Vietnam, Lao Cai province, Sapa, below Ban Khoang Village, wet ground, possibly old paddy, flowers pale mauve, $1245 \mathrm{~m}, 22^{\circ} 24^{\prime} 28^{\prime} \mathrm{N}$, 10347'20.9'E, 30 March 1997, K. D. Rushforth, D. M. Chamberlain, J. Cubey 4452 [E00110017]. N. Vietnam, Vinh Phu, Tam Dao, 31 March 1984, L. Averyanov et al., LX-VN 1323 (LE). N. Vietnam, Vinh Phu, Tam Dao, forest on very steep mountain slope, 1000 M, flowers light violet, 23 January 1988, L. Averyanov et al., $L X-V N 3864$ (LE). N. Vietnam, Cao Bang province, Nguyen Binh district, Nguyen Binh municipality, $22^{\circ} 37^{\prime} \mathrm{N}, 105^{\circ} 52^{\prime} \mathrm{E}$, about $41 \mathrm{~km}$ to $\mathrm{W}$ from Cao Bang town, elevation from Le A pass to Na Ni mt. peak at elev. 1400-1900 m a.s.l., old secondary closed evergreen wet mountain forest on soils developed on granite and shale rocks, herb up to $0.5 \mathrm{~m}$ hg on wet granite outcrops in shady place, flowers light lilac, tepals with light yellow marks, rare, 11-12 November 1998, Averyanov L., N. Q. Binh, N. T. Hiep, P. K. Loc, N. X. Tam, CBL 70 (HN, LE, P). N. Vietnam, Cao Bang province, Bao Lac district, Yen Lac municipality, vicinities of Yen Lac village, $22^{\circ} 44^{\prime} \mathrm{N}, 105^{\circ} 50^{\prime} \mathrm{E}$, about $44 \mathrm{~km}$ to NWW from Cao Bang town, secondary open forest on alluvial foothills of remnant limestone ridge at elev. 1100-1200 m a.s.1., terrestrial and lithophyte herb on wet shadow slopes along road, not common, 15 November 1998, Averyanov L., N. T. Hiep, P. K. Loc, N. X. Tam, CBL 286 (HN, LE, MO). N. Vietnam, Cao Bang province, Bao Lac district, Yen Lac municipality, vicinities of Yen Lac village, $22^{\circ} 44^{\prime} \mathrm{N}$, $105^{\circ} 50^{\prime} \mathrm{E}$, secondary open broad-leaved evergreen forest on steep slopes and bluffs of limestone remnant karst ridge at elev. $1100 \mathrm{~m}$ a.s.l., lithophytic herb on open wet rocks, flowers pale blue, tepals with yellowish spots, not common, 16 April 1999, $P$. K. Loc, P. H. Hoang, Averyanov L. CBL 1444 (HN, LE, MO). N. Vietnam, Ha Giang province, Hoang Su Phi district, Ho Thau municipality, around Trung Thanh village, $22^{\circ} 37^{\prime} 24^{\prime \prime} \mathrm{N}, 104^{\circ} 38^{\prime} 00^{\prime \prime} \mathrm{E}$ at elev. 900-1000 m a.s.1., remnants of heavily logged primary and secondary closed evergreen broad-leaved forest on very steep slopes of mountains composed with shale and granite with quartzite, terrestrial herb in open secondary forest with bamboo, flowers light blue to white, sepals with median yellow spot, locally common, 9 March 2005, L. Averyanov, P. K. Loc, N. T. Vinh, A. Averyanova, HAL 6622 (HN, MO). N. Vietnam, Cao Bang province, Nguyen Binh dis-

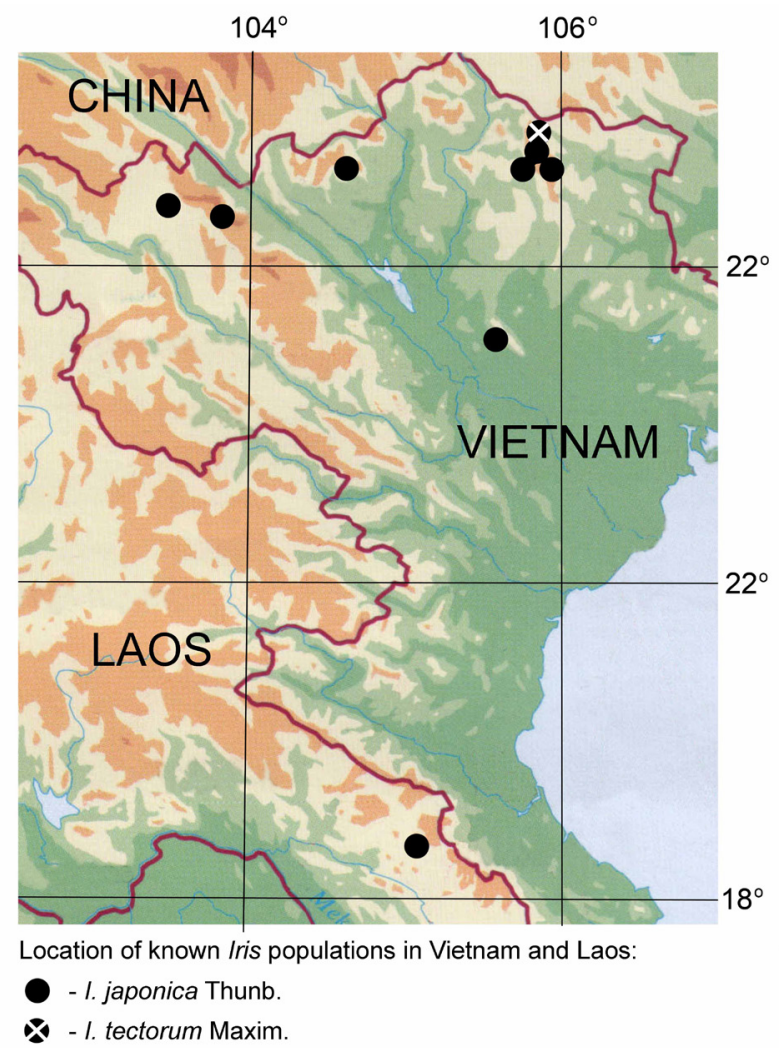

Fig. 1. Distribution of Iris japonica and I. tectorum in eastern Indochina. 
trict, Ca Thanh municipality, Ta Pin village, around point $22^{\circ} 43^{\prime} 56.4^{\prime \prime} \mathrm{N}, 105^{\circ} 51^{\prime} 16.4^{\prime \prime} \mathrm{E}$, primary coniferous forest with Pseudotsuga sinensis along highly eroded rocky limestone ridge at elevation about $1400 \mathrm{~m}$ a.s.l., shrub to $2 \mathrm{~m}$ tall among secondary shrubs on steep alluvial slope of limestone ridge, flowers white with pink tint, common, 3 October 2013, L. Averyanov, N. T. Hiep, L. M. Tuan, N. S. Khang, T. Maisak, L. Osinovets, CPC 5366a (LE photo). N. Vietnam, Cao Bang province, Bao Lac district, Hong An municipality, Mi Lung village, primary broad-leaved and mixed humid evergreen forest on very steep slopes and along rocky ridge composed with solid crystalline highly eroded lime- stone at elevation $1500-1550 \mathrm{~m}$ a.s.l. around point $22^{\circ} 50^{\prime} 01.3^{\prime \prime} \mathrm{N}, 105^{\circ} 50^{\prime} 05.7^{\prime \prime} \mathrm{E}$, terrestrial herb to $1 \mathrm{~m}$ tall among rocks in rather open place, flowers light dull blue, common, 20 November 2014, L. Averyanov, N. T. Hiep, N. S. Khang, T. Maisak, L. Osinovetz, CPC 7532 ass. (LE - photo).

Habitat, phenology and conservation status. Terrestrial or lithophytic herb or undershrub to $1.5(2) \mathrm{m}$ tall. Open primary and secondary evergreen forest margins, open secondary scrub, wet secondary grasslands on rocky mountain slopes on soils derived from any kind of rocks, commonly among rock outcrops. (500)800-2000 m a.s.l. Flowers in any time of the year with maximum in March - May.

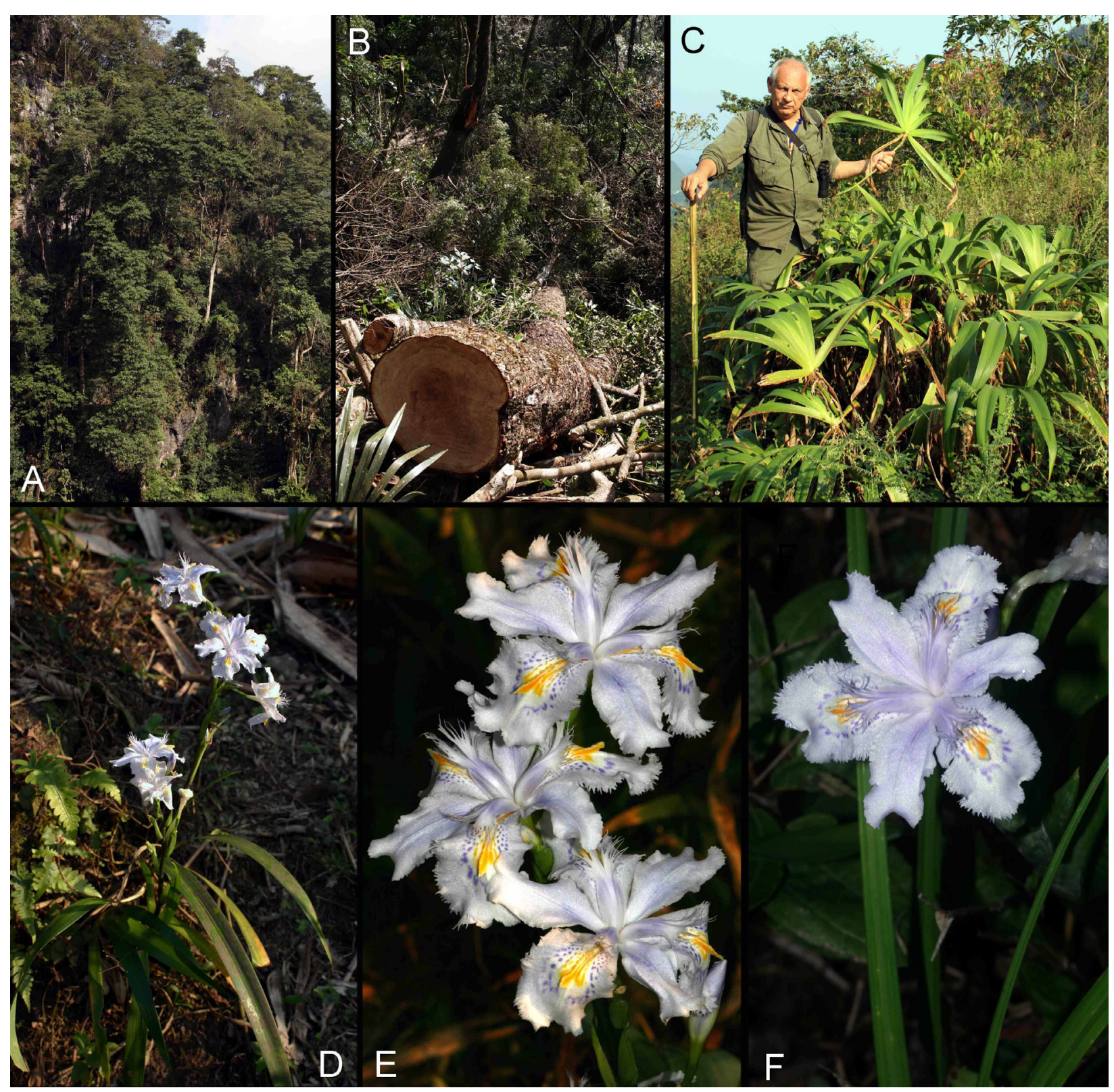

Fig. 2. A, B - Typical habitat of Iris japonica and I. tectorum in northern Vietnam (Cao Bang province, primary limestone forest, $1500-1550 \mathrm{~m}$ a.s.1. CPC 7532). C-F - I. japonica in natural habitats (C - CPC 5366a; D, E - HAL 6622; $\mathrm{F}-\mathrm{CPC} 7532$ ass.). All photos by L. Averyanov and T. Maisak. 
Occurs sporadically, locally sometimes common Lac district, Hong An and Yen Lac municipalities; and even abundant. Estimated IUCN Red List Nguyen Binh district, Ca Thanh and Nguyen Binh status - LC.

Distribution. Laos: province Bolikhamxai (Ban municipalities), Ha Giang (Hoang Su Phi district, Nape town). Vietnam: provinces Cao Bang (Bao cality), Lao Cai province (Sa Pa town), Vinh Phuc

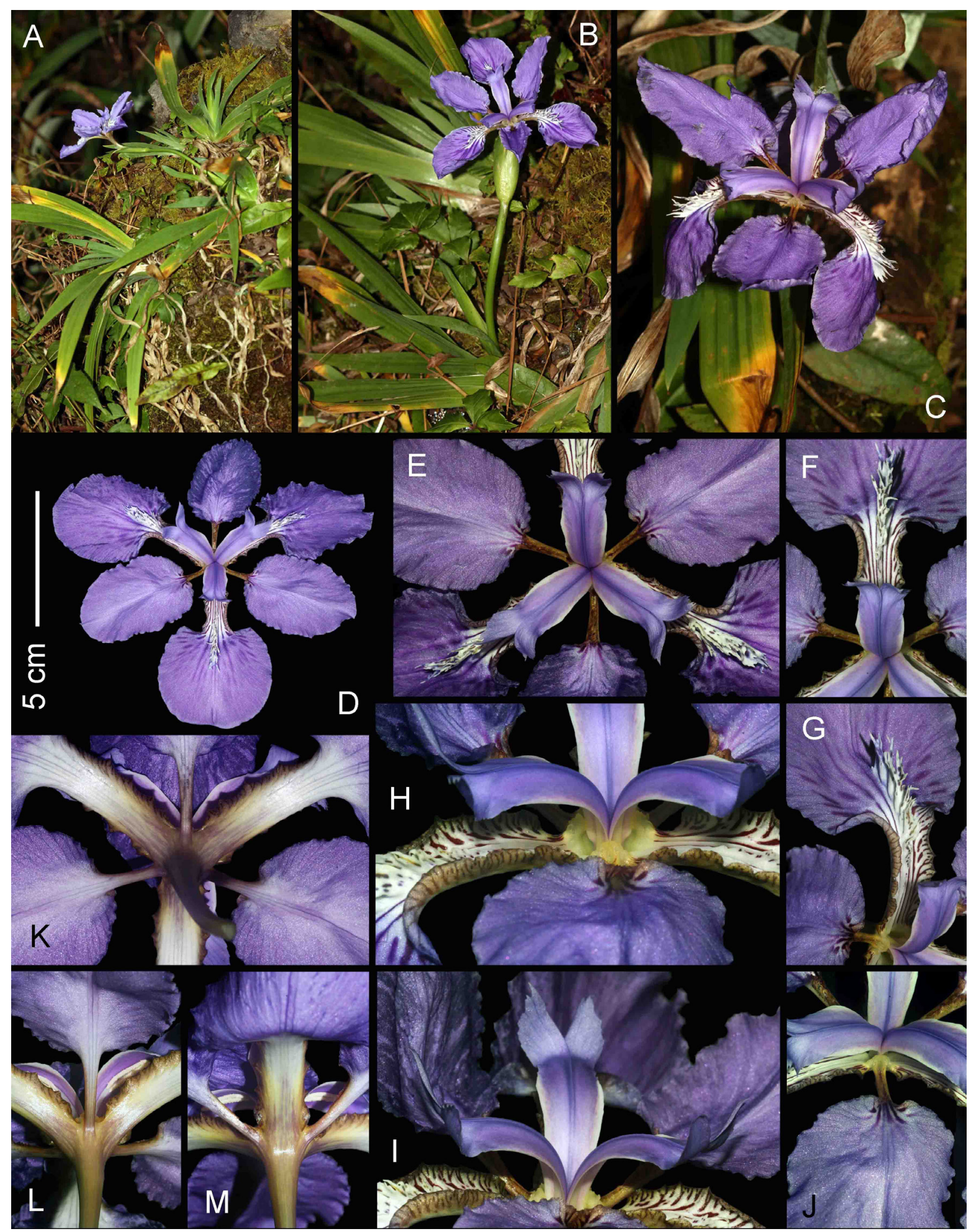

Fig. 3. A-C - Iris tectorum in natural habitat. D - Flower opened in cultivation. $\mathrm{E}-\mathrm{M}$ - details of flower (CPC 7532). All photos by L. Averyanov. 
province (Tam Dao town). China, Japan, N Myanmar.

Notes. This species is sometime cultivated in highland areas of northern Vietnam and probably occasionally naturalizes. Flowers in observed Vietnamese population vary from light violet or pale lilac to almost pure white. The species was casually overlooked in the latest treatise of the Laotian flora by Newman et al. (2007). Meanwhile, locality in Laos near Ban Nape town represents probably southernmost location of the Iris genus in Asia.

3. Iris tectorum Maxim. 1870, Bull. Acad. Imp. Sci. Saint-Petersburg, 15, 3: 380; Y. T. Zhao et al., 2000, Fl. China, 24: 308.

=I. tomiolopha Hance, 1872, J. Bot. 10: 229.

$=$ I. rosthornii Diels, 1900, Bot. Jahrb. Syst. 29, 2: 261 .

Fig. 1, 2a, b, 3 .

Described from Japan ("Hab. circa Yokohamam ... in vico Kamakura in hortis rusticanorum culta").

Lectotype ("Japonia, Yokohama, Kamakura, cult. 15/27 April 1862, [fl.], Maximowicz 1129" [LE01011510!], Grabovskaya-Borodina in Catalogue ..., 2004: 106). Syntypes ("Japonia, Yokohama, in tectis ... vicorum nec non into ... in agris, frequens, [fl.], 26 April/8 Mai 1862, Maximowicz s.n." [LE01011511!]; "Japonia, Yokohama, ad agriorum margines, [fl.], 3/15 Mai 1862, Maximowicz s.n." [LE01011512!]; "Japonia, Yokohama, [fl.], 1862, Maximowicz s. n." [K000499082!]).

Studied specimens. N. Vietnam, Cao Bang province, Bao Lac district, Hong An municipality, Mi Lung village, primary broad-leaved and mixed humid evergreen forest on very steep slopes and along rocky ridge composed with solid crystalline highly eroded limestone at elevation $1500-1550 \mathrm{~m}$ a.s.l. around point $22^{\circ} 50^{\prime} 01.3^{\prime \prime} \mathrm{N}, 105^{\circ} 50^{\prime} 05.7^{\prime \prime} \mathrm{E}$, lithophytic acaulescent creeping herb on open mossy boulders, flowers fragrant, dark blue, rare, 20 November 2014, L. Averyanov, N. T. Hiep, N. S. Khang, T. Maisak, L. Osinovetz, CPC 7532 (CPC Herbarium, LE).

Distribution. Vietnam: province Cao Bang (Bao Lac district, Hong An municipality). China, Japan,
S Korea (cult.), N Myanmar. Naturalized in Bhutan and India.

Habitat, phenology and conservation status. Lithophytic rhizomatous creeping herb on exposed mossy limestone outcrops. Primary mixed and coniferous forests (with Fokienia hodginsii, Pinus wangii and Tsuga chinensis) on karstic rocky limestone. 1500-1550 m a.s.l. Flowers in November - December (May - June). Very rare. Estimated IUCN Red List status - DD.

Notes. Habitats in China were reported as "forest margins, sunny banks, meadows, damp places, beside water; 500-3500 m." (Zhao et al., 2000). Species is presently widely cultivated in China as ornamental plant and often naturalizes. In Vietnam it was found in primary plant community where species certainly presents aboriginal element of the flora. Collected living specimens grow well in cultivation and form distinctly larger leaves and flowers than were observed in nature in the same clone.

\section{Acknowledgements}

Field works results of which are presented in this paper were partly supported by investigation programs of U.S.A. National Geographic Society ("Exploration of primary woods along constructed highway Hanoi - Ho Chi Minh for their sustainable conservation in limits of Ha Tinh and Nghe An provinces of central Vietnam"), Rufford Small Grant for Nature Conservation ("Mapping and assessment of Xanthocyparis vietnamensis subpopulations in Cao Bang, Ha Giang and Lang Son provinces, Vietnam, 2014-2015") and Russian Foundation for Basic Research ("Plant taxonomy, geography and biology in local floras of eastern Indochina'), 15-04-00419A. Laboratory works were carried out in the framework of institutional research project of the Komarov Botanical Institute of the Russian Academy of Sciences. Authors are highly indebted to staff members and professional growers of the Botanical Garden department of the Komarov Botanical Institute, particularly to Mrs Z. Zaitseva and Mrs I. Kutuzova who skillfully kept our living Iris collections for our research.

\section{REFERENCES}

Catalogue of the type specimens of East-Asian vascular plants in the Herbarium of the Komarov Botanical Institute (LE). Part 1 (Japan and Korea) (2004) V. I. Grubov (ed.). KMK Scientific Press, Moscow -St. Petersburg, 188 pp. [In Russian]. (Каталог типовых образцов сосудистых растений Восточной Азии, хранящихся в Гербарии Ботанического института имени В. Л. Комарова (LE). Ч. 1 (Япония и Корея). М. - СПб.: Тов-во науч. изд-й KMK, 2004. 188 c.). 
Gagnepain F. (1934) Iridacees. In: H. Lecomte, H. Humbert (eds). Flore Génerale de l'Indo-Chine. Vol. 6, 5. Masson et Cie, Paris, pp. 673-677.

Ho P. H. (2000) An illustrated flora of Vietnam. Vol. 3. Nha Xuat Ban Tre, Ho Chi Minh, 1020 pp.

Newman M., Ketphanh S., Svengsuksa B., Thomas P., Sengdala K., Lamxay V., Armstrong K. (2007) A checklist of the vascular plants of Lao PDR. Royal Botanic Garden Edinburgh, Edinburgh, 394 pp.

Nguyen T. D. (2005) Iridaceae Juss. 1789. - HO LA DON, LAY ON. In: Nguyen Tien Ban at al. (eds). Danh Luc Cac Loai Thuc Vat Viet Nam [Checklist of Plant Species of Vietnam]. Vol. 3. Nganh Moc Lan - Magnoliophyta (Nganh Hat Kin - Angiospermae) Cac Ho Tu 181 (Santalaceae) Den 265 (Typhaceae). Agriculture Publ. House, Ha Noi, p. 481 [In Vietnamese].

Zhao Y. T., Noltie H. J., Mathew B. (2000) Iridaceae. In: Z. Y. Wu, P. H. Raven (eds). Flora of China. Vol. 24. Science Press \& St. Louis: MBG Press, Beijing, pp. 297-313. 